\title{
Fabaceae of the Rio São Francisco River sub-basin, Nova Marilândia, Mato Grosso, Brazil
}

\author{
Rosilene Rodrigues Silva ${ }^{1,3}$ \& Eliane Semidei de Souza-Lima ${ }^{2}$ \\ ${ }^{1}$ Vale MCR, Gerência de Área Meio Ambiente Centro-Oeste, CP 221, CEP 79301-970, Corumbá, MS, Brasil \\ ${ }^{2}$ Programa de Pós-graduação em Biologia Vegetal, Universidade Federal de Mato Grosso do Sul-UFMS, \\ CP 549, 221, CEP 79070-900, Campo Grande, MS, Brasil \\ ${ }^{3}$ Corresponding author: Rosilene Rodrigues Silva, e-mail: rosilener663@gmail.com
}

SILVA, R.R. \& SOUZA-LIMA, E.S. Fabaceae in the São Francisco River sub-basin, Nova Marilândia, Mato Grosso, Brazil. Biota Neotrop. 13(2): http://www.biotaneotropica.org.br/v13n2/en/abstract?shortcommunication+bn00413022013

\begin{abstract}
The watershed of the São Francisco River is a large complex of headwaters of the Paraguay River, the main river of the Pantanal Matogrossense. Considering that Fabaceae are pointed out as the main family in floristic composition of various Brazilian biomes, however in some regions of Brazil is still little known upon the taxa, particularly in the Northern part of the Central-West, this study aimed to present a list of taxa occurring in the sub-basin of the São Francisco River, municipality of Nova Marilândia, State of Mato Grosso. For the taxa we give information on habit, vegetation, data on geographic distribution, potential use, successional strategy and dispersal syndrome, to subsidize habitat restoration projects. We recorded a total of 44 taxa, belonging to 25 genera. Inga stood out as the main genus in number of species. Among the identified taxa we found eight new records for the State of Mato Grosso: Chamaecrista brevicalyx (Benth.) H. S. Irwin \& Barneby var. brevicalyx, Inga alba (Sw.) Willd., I. capitata Desv., I. heterophylla Willd., I. marginata Willd., I. nobilis Willd., Mimosa nitens Benth. and Ormosia coarctata Jacks. Vouchers are kept in the Herbarium UFMT.

Keywords: Leguminosae, Inga, neotropical flora, Pantanal, riparian vegetation.
\end{abstract}

SILVA, R.R. \& SOUZA-LIMA, E.S. Fabaceae na sub-bacia do Rio São Francisco, Nova Marilândia, Mato Grosso, Brasil. Biota Neotrop. 13(2): http://www.biotaneotropica.org.br/v13n2/pt/abstract?shortcommunication+bn00413022013

Resumo: A sub-bacia do Rio São Francisco compreende um imenso complexo de nascentes do Rio Paraguai, principal formador do Pantanal Matogrossense. Considerando que Fabaceae é apontada como a principal família na composição florística de vários biomas brasileiros, porém, em determinadas regiões do Brasil ainda se conhece pouco sobre seus táxons, particularmente na região norte do Centro-Oeste brasileiro, este trabalho teve por objetivo apresentar uma lista dos táxons ocorrentes na sub-bacia do Rio São Francisco, município de Nova Marilândia, estado do Mato Grosso. Para os táxons são fornecidas informações sobre o hábito, vegetação, dados de distribuição geográfica, uso potencial, estratégia sucessional e síndrome de dispersão para subsidiar projetos de recuperação ambiental. Um total de 44 táxons foi registrado, pertencendo a 25 gêneros. Inga se destacou como o principal gênero em número de representantes. Dentre os táxons identificados, foi observada a ocorrência de oito novos registros para o estado do Mato Grosso, que são: Chamaecrista brevicalyx (Benth.) H. S. Irwin \& Barneby var. brevicalyx, Inga alba (Sw.) Willd., I. capitata Desv., I. heterophylla Willd., I. marginata Willd., I. nobilis Willd., Mimosa nitens Benth. e Ormosia coarctata Jacks. Os vouchers estão depositados no Herbário UFMT.

Palavras-chave: Leguminosae, Inga, flora neotropical, Pantanal, vegetação ciliar. 


\section{Introduction}

Leguminosae or Fabaceae is the third largest family of Angiosperms with 19.327 species and 727 genera arranged in 36 tribes (Lewis et al. 2005). In Brazil this family is represented by 212 genera and 2719 species (Lima et al. 2012), that are present in all biomes (Souza \& Lorenzi 2008). The family is represented by three subfamilies, Caesalpinioideae, Mimosoideae and Papilionoideae, morphologically different and distributed in all terrestrial ecosystems (Polhill et al. 1981, Lewis et al. 2005).

Riparian forests are fragile formations, but with great floristic richness (Rodrigues \& Nave 2004, Pereira 2006) and, despite their fragility, play a relevant role in maintenance of biodiversity, representing areas of refuge and conservation of fauna and flora, forming ecological corridors and assuring maintenance of quantity and quality of water (Botelho \& Davide 2002).

The riparian formations found in the sub-basin of the São Francisco River are part of the huge Upper Paraguay River basin that is considered one of the most relevant hydrographic basins for being integrated to Pantanal Biome. In floristic composition works Fabaceae is pointed out as the main family (Duarte 2007, Nunes da Cunha 1990, 1998, Nunes da Cunha \& Junk 2000, Pott \& Pott 1994, 1999, Soares 2009).

North of the municipality of Nova Marilândia, riparian formations were fragmented in the past by alluvial extraction of diamonds during various decades along the drainage lines, and in the present, by agricultural activity. The scenario of degradation motivates environmental organs to take initiatives to recover these degraded areas. However, the lack of knowledge on floristics hinders such action, as studies in the region are scarce on the headwaters of the Paraguay River (Soares 2009).

Concerning regional richness of the family Leguminosae in Mato Grosso, Silva (2010) recorded 99 species distributed in 54 genera in a floristic survey in the Pantanal sub-region of Poconé, with confirmation of one new record. Furthermore, in the Pantanal subregion of Barão de Melgaço, Silva (2011) found 40 taxa, distributed in 23 genera, and pointed out two new records.

Therefore, the aims of this study was the identification of taxa of Fabaceae occurring in the sub-basin of the São Francisco River, to subsidize projects of vegetation recovery in this region, through information on geographic distribution, potential use, successional classification and dispersion syndrome of plants.

\section{Material and Methods}

Systematic botanical collections were made in the sub-basin of the São Francisco River, within the limits of the municipality of Nova Marilândia, between the coordinates $14^{\circ} 30^{\prime} 00$ - $14^{\circ} 15^{\prime} 00^{\prime \prime}$ $\mathrm{S}$ and $57^{\circ} 06^{\prime} 00^{\prime \prime}-56^{\circ} 48^{\prime}-56^{\circ} 00^{\prime} \mathrm{W}$, state of Mato Grosso, CentralWest region. The São Francisco River and its affluents are part of the headwaters of the Paraguay River and occupy an estimated area of 78.413 ha, within four municipalities: Nova Marilândia, which concentrates above $90 \%$ of the headwaters, Nortelândia, Arenápolis and Santo Afonso. In the sub-basin of the São Francisco River one can recognized three phytoecological regions: Seasonal Semidecidual Forest, Contact Savanna/Seasonal Semideciduous Forest and Savanna, occurring in a narrow belt in the extreme North of the area (Brasil 1982).

In the floristic survey we considered all habits. All plants in reproductive phase (flower and/or fruit) were collected and incorporated into the collection of the Herbarium UFMT (acronyms according to Thiers 2012).

The list of taxa and infra-specific categories was based on six field expeditions with duration of five days each, between 2007 and 2009, during the dry and rainy seasons. Also, we examined materials from the municipality of Nova Marilândia deposited in the Herbarium UFMT.

The classification of Fabaceae in subfamilies followed Lewis et al. (2005). The concept of life forms followed GuedesBruni et al. (2002), the geographic distribution followed Lima et al. (2012), the potential use followed Lorenzi $(2002,2009)$ and, Pott \& Pott (1994), the successional classification followed Whitmore (1984) and the dispersal syndrome followed Van der Pijl (1982). Taxa identification was achieved consulting the pertinent literature and comparing material deposited in the Herbaria UFMT and RB.

\section{Results and Discussion}

In the floristic survey of the sub-basin of the São Francisco River we identified a total of 44 specific and infraspecific taxa of Fabaceae, distributed in 25 genera and three subfamilies (Table 1). Of these taxa, 14 belong to the subfamily Caesalpinioideae, 17 to Mimosoideae and 13 to Papilionoideae. In our study we point out the Mimosoideae as the richest subfamily of Fabaceae compared to the other two. So, our results differ from most floristic studies, in which Papilionoideae stand out as the most representative subfamily (Almeida et al. 2007, Dutra et al. 2008, Lima et al. 2007, Córdula et al. 2008, Miotto et al. 2008).

Considering Caesalpinioideae, the most expressive genera were Bauhinia and Senna (3 spp. each). In Mimosoideae, the most representative genus was Inga ( $8 \mathrm{spp} ., 1$ subsp.), followed by Mimosa (4 spp.). In Papilionoideae Stylosanthes was the best represented genus (3 ssp.), and next Ormosia (2 ssp.). Among the recorded species of Caesalpinioideae, we do confirm a new record for the state of Mato Grosso: Chamaecrista brevicalyx (Benth.) H.S. Irwin \& Barneby var. brevicalyx. Furthermore, among Mimosoideae we have confirmed six new records, five belonging to the genus Inga, which are: I. alba (Sw.) Willd., I. capitata Desv., I. heterophylla Willd., I. marginata Willd., and I. nobilis Willd., plus a new record belonging to the genus Mimosa, that is M. nitens Benth. And for Papilionoideae we show a new record in the genus Ormosia, namely O. coarctata Jacks. These taxa were not mentioned in the studies of flora of the state of Mato Grosso (Dubs 1998) and in the list of phanerogamic flora of the Pantanal (Pott \& Pott 1994, 1999), neither in the list of species of flora of Brazil (Lima et al. 2012), what reinforces the importance of inventories of local and regional floras.

Chamaecrista brevicalyx var. brevicalyx occurs in the regions Northeast (PI, PB, PE, BA) and Southest (MG), being found in the Caatinga stricto sensu, rupestriane grassland and Cerrado (Souza \& Bortoluzzi 2012), and we found it in vegetation of Cerrado. With regard to species of Inga, I. alba is cited for the regions North (RR, AP, AM, TO, AC, RO), Northeast (MA, CE), Central-West (GO) and Southwest (MG), occupying the biomes Amazonia and Cerrado (Garcia \& Fernandes 2012). According to

Garcia \& Fernandes (2012), I. capitata occurs in the regions North (RR, AP, PA, AM, AC, RO), Northeast (MA, PB, PE, BA, SE), Southeast (MG, ES, SP, RJ), occupying the domains of Amazonia and Atlantic Forest, while we found it in degraded alluvial forest. On the other hand, I. heterophylla is restricted to Amazonia, with distribution only in region North (PA, AM, AC). Another species, I. marginata occurs in the regions North (AP, PA, AM, AC), Northeast (CE, BA), Central-West (GO, DF, MS), Southeast (MG, ES, SP, RJ), South (PR, SC, RS), occupying three biomes, Amazonia, Cerrado and Atlantic Forest (Pennington 1997, Garcia 1998). Inga nobilis presents distribution in North (AM, AC, RO) and Northeast (BA). It is worth mention that two species of Inga were found in riparian forest, I. alba and I. marginata, while another two in seasonal 


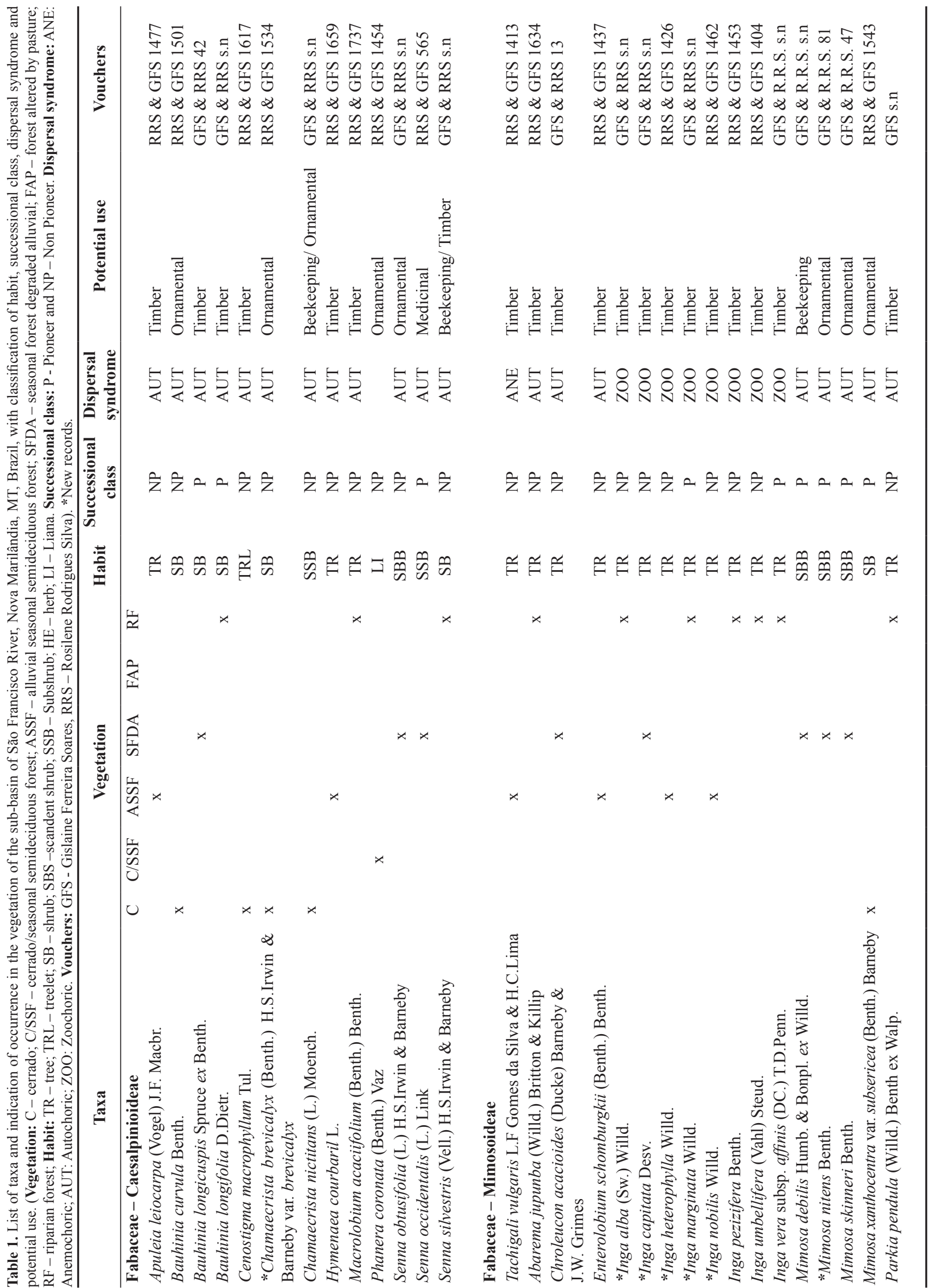


Silva, R.R. \& Souza-Lima, S.E.

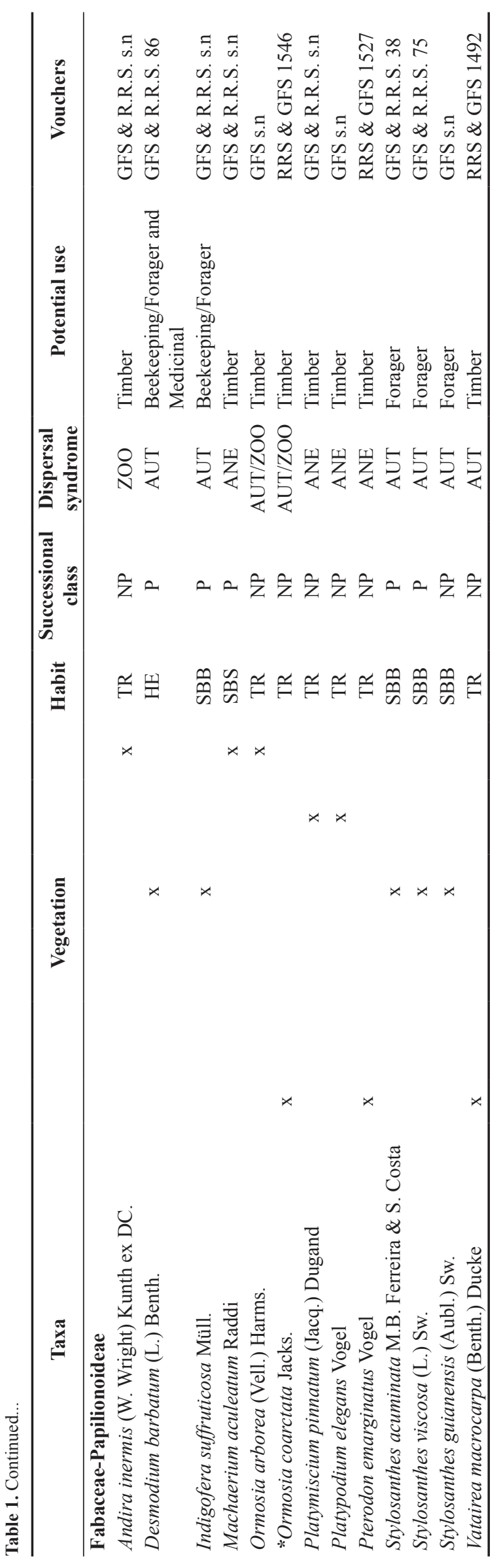


semideciduous alluvial forest, that are I. heterophylla and I. nobilis. The species Mimosa nitens has occurrence in the regions North (TO) and Central-West (GO), being restricted to the Cerrado biome (Dutra \& Morim 2012); in the sub-basin of São Francisco River we verified its occurrence in degraded seasonal alluvial forest. The species Ormosia coarctata is cited for the region North (PA), restricted to the phytogeografic domain of Amazonia (Meireles 2012) and we found it in riparian forest.

In vegetation of degraded seasonal semideciduous alluvial forest we found most species (15), followed by riparian forest with 12, seasonal semideciduous alluvial forest with eight, cerrado with seven, antropized forest with pasture and cerrado/seasonal semideciduous forest with one species (Table 1). In antropized forest, among the observed species, the presence of Senna occidentalis (L.) Link and $S$. silvestris (Vell.) H.S.Irwin \& Barneby (Caesalpinioideae) and Mimosa debilis Humb. \& Bonpl. ex Willd. (Mimosoideae), reported by Pott \& Pott (1994) as indicators of disturbed areas. The taxa Macrolobium acaciifolium (Benth.) Benth. (Caesalpinioideae), Abarema jupunba (Willd.) Britton \& Killip, Inga alba (Sw.) Willd., I. marginata Willd., I. pezizifera Benth., I. umbellifera (Vahl) Steud. and I. vera subsp. affinis (DC.) T.D. Penn. (Mimosoideae) recorded in vegetation of riparian forest, were pointed by Garcia (1998), Lorenzi (2002) and Pennington (1997) as characteristic elements of this type of vegetation.

Most arboreal taxa presented are trees, amounting to $56.8 \%$ trees, $20.4 \%$ of subshrubs, $18.2 \%$ of shrubs and $2 \%$ of herbs and lianas, respectively each.

Considering the classifications of the species in ecological groups, our results (Tabela 1) pointed at two groups: pioneer (tolerant of light) and non pioneers; among the non pioneers are: the secundary (tolerant of shade) and the climacic (species which can grow and develop under the canopy). Most species inventored (30 ssp.; 68.2\%) fit in the group of non pioneers (secondary), and (14 ssp; 31.8\%) in the group of pioneers. Among the pioneers of Caesalpinioideae (Bauhinia longicuspis Spruce ex Benth., B. longifolia D.Dietr. and Senna occidentalis (L.) Link); among the initial secondary (B. curvula Benth., Cenostigma macrophyllum Tul, Chamaecrista brevicalyx var. brevicalyx, C. nictitans (L.) Moench., Phanera coronata (Benth.) Vaz, Senna obtusifolia (L.) H.S.Irwin \& Barneby, S. silvestris (Vell.) H.S. Irwin \& Barneby and Tachigali vulgaris L.F Gomes da Silva \& H.C. Lima); among the late secundary, Hymenaea courbaril L.; and among the climax, only Apuleia leiocarpa (Vogel) J.F. Macbr. (Lorenzi 2002). Among the pioneers species of Mimosoideae (Inga marginata Willd., Inga vera subsp. affinis (DC.) T.D.Penn., Mimosa debilis Humb. \& Bonpl. ex Willd., M. nitens Benth. M. skinneri Benth. and M. xanthocentra var. subsericea (Benth.) Barneby); among the initial secondary species (Abarema jupunba (Willd.) Britton \& Killip, Chloroleucon acacioides (Ducke) Barneby \& J.W. Grimes, Inga alba (Sw.) Willd., I. capitata Desv., I. heterophylla Willd., I. nobilis Willd., Inga pezizifera Benth., I. umbellifera (Vahl) Steud. and Samanea tubulosa (Benth.) Barneby \& J.W. Grimes); and among late secondary (Enterolobium schomburgkii (Benth.) Benth. and Parkia pendula (Willd.) Benth ex Walp.). Among the pioneers of Papilionoideae (Desmodium barbatum (L.) Benth., Indigofera suffruticosa Müll., Machaerium aculeatum Raddi, Stylosanthes acuminata M.B. Ferreira \& S. Costa, S. viscosa (L.) Sw.); among the initial secundary (Andira inermis (W. Wright) Kunth ex DC. and Stylosanthes guianensis (Aubl.) Sw.); and among the late secondary (O. arborea (Vell.) Harms., Ormosia coarctata Jacks., Platymiscium pinnatum (Jacq.) Dugand, Platypodium elegans Vogel, Pterodon emarginatus Vogel and Vatairea macrocarpa (Benth.) Ducke).

For the dispersal syndromes (Table 1) we observed predominance of the autochoric strategy (dispersal diaspores through gravity or by explosion) in both studied formations. This is not an expected pattern for tropical forests that have between $50 \%$ and $90 \%$ of trees and shrubs with zoochorous fruits (Howe \& Smallwood 1982). Autochory occurred in 28 species $(63.6 \%)$, followed by zoochory (dispersal by animals or sticky structures) in nine species $(20.5 \%)$ and anemocory (dispersal by wind) in five species $(11.3 \%)$. Autochoric species possibly depend on a secondary dispersor, since many do not have efficient mechanisms for dispersal (Van der Pijl 1982). Also, two species were classified as autochoric and zoochoric on the basis of the initial dehiscence of fruits with later exposure of arilum, i. e., an ornamentation of the seed, as observed in Ormosia arborea (Vell.) Harms and $O$. coarctata Jacks., suggesting participation of a secondary agent in dispersal of these species. Zoochory predominated in riparian forests, which occur in habitats with higher water availability, consequently allowing maintenance of a fauna which needs shelter, food and water (Marinho-Filho \& Gastal 2000).

The Fabaceae species surveyed is this study can be utilized in projects aimed at environmental rehabilitation of degraded areas in the region of sub-basin of the São Francisco River.

\section{Acknowledgments}

To Gislaine Ferreira Soares and to Libério Amorim for help in field collecttion. To the curator of Herbarium RB, Dra. Rafaela Campostrini Forzza, for kind assistance during our visit. To Dr. Arnildo Pott for the English version.

\section{References}

ALMEIDA, A., FÉLIX, W.J.P., ANDRADE, L.A. \& FÉLIX, L.P. 2007. Leguminosae na flora de inselbergues no Estado da Paraíba, Nordeste do Brasil. Rev. Brasil. Bioc. 5(2):750-752.

BOTELHO, S.A. \& DAVIDE, A.C. 2002. Métodos silviculturais para recuperação de nascentes e recomposição de matas ciliares. In Anais do Simpósio Nacional Sobre Recuperação de Áreas Degradadas. Belo Horizonte, p.123-145.

BRASIL. Ministério das Minas e Energia. Secretária Geral. Projeto RADAMBRASIL. 1982. Cuiabá: geologia, geomorfologia, pedologia, vegetação e uso potencial da terra. Ministério das Minas e Energia, Rio de Janeiro. Folha SD-21. Serie Levantamento de Recursos Naturais, n.26.

CÓRDULA, E., QUEIROZ, L.P. \& ALVES, M. 2008. Ckecklist da flora de Mirandiba, Pernambuco: Leguminosae. Rodriguésia 59(3):597-602.

DUARTE, T.G. 2007. Florística, fitossociologia e relações solos-vegetação em Floresta Estacional Decidual em Barão de Melgaço, Pantanal de Mato Grosso. Tese de Doutorado, Universidade Federal de Viçosa, Viçosa.

DUBS, B. 1998. Prodromus Florae Matogrossensis. The Botany of Mato Grosso, Betrona-Verlag, Küsnacht. Part 1. Checklist of Angiosperm, part 2. Types from Mato Grosso.

DUTRA, V.F., GARCIA, F.C.P., LIMA, H.C. \& QUEIROZ, L.P. 2008. Diversidade florística de Leguminosae Adans. em áreas de campos rupestres. Megadiversidade 4:163-171.

DUTRA, V.F. \& MORIM, M.P. 2012. Mimosa. In Lista de Espécies da Flora do Brasil (Jardim Botânico do Rio de Janeiro) Jardim Botânico do Rio de Janeiro, Rio de Janeiro. http://floradobrasil.jbrj.gov.br/2012/FB031245 (último acesso em 20/06/2012).

GARCIA, F.C.P. 1998. Relações Sistemáticas e Fitogeografia de Inga Mill. (Leguminosae- Mimosoideae) nas florestas da costa sul e sudeste do Brasil. Tese de doutorado. Universidade Estadual Paulista, Rio Claro.

GARCIA, F.C.P. \& FERNANDES, J.M. 2012. Inga. In Lista de Espécies da Flora do Brasil. (Jardim Botânico do Rio de Janeiro), Rio de Janeiro. http://floradobrasil.jbrj.gov.br/2012/FB023005 (último acesso em 20/06/2012). 
GUEDES-BRUNI, R.R., MORIM, M.P., LIMA, H.C. \& SYLVESTRE, L.S. 2002. Inventário florístico. In Manual metodológico para estudos botânicos na Mata Atlântica (L.S. Sylvestre \& M.M.T. Rosa, ed.). Universidade Federal Rural do Rio de Janeiro, Seropédica, p.24-49.

HOWE, H. F. \& SMALLWOOD, J. 1982. Ecology of seed dispersal. Ann. Rev. Ecol. and Syst. 13:201-228. http://dx.doi.org/10.1146/annurev. es.13.110182.001221

LEWIS, G., SCHRIRE, B., MacKINDER, B. \& LOCK, M. 2005. Legumes of the world. Royal Botanic Gardens, Kew.

LIMA, L.C.P., GARCIA, F.C.P. \& SARTORI, A.L.B. 2007. Leguminosae nas florestas estacionais do Parque Estadual do Itacolomi, Minas Gerais, Brasil: ervas, arbustos, subarbustos, lianas e trepadeiras. Rodriguésia 58(2):331-358.

LIMA, H.C., QUEIROZ, L.P., MORIM, M.P., SOUZA, V.C., DUTRA, V.F., BORTOLUZZI, R.L.C., IGANCI, J.R.V., FORTUNATO, R.H., VAZ, A.M.S.F., SOUZA, E.R., FILARDI, F.L.R., VALLS, J.F.M., GARCIA, F.C.P., FERNANDES, J.M., SILVA, R.C.V. M., FORTUNA-PEREZ, A.P., MANSANO, V.F., MIOTTO, S.T.S., TOZZI, A.M.G.A., MEIRELES, J.E., LIMA, L.C.P., OLIVEIRA, M.L.A.A., FLORES, A.S., TORKE, B.M., PINTO, R.B., LEWIS, G.P., BARROS, M.J.F., RIBEIRO, R.D., SCHÜTZ, R., PENNINGTON, T., KLITGAARD, B.B., RANDO, J.G., SCALON, V.R., CARDOSO, D.B.O.S., COSTA, L.C., SILVA, M.J., MOURA, T.M., BARROS, L.A.V. SILVA, M.C.R., QUEIROZ, R.T., SARTORI, A.L.B. \& CAMARGO, R. 2012. Fabaceae. In Lista de Espécies da Flora do Brasil. Jardim Botânico do Rio de Janeiro, Rio de Janeiro. http://floradobrasil.jbrj.gov.br/2012/FB000115 (último acesso em 20/06/2012).

LORENZI, H. 2002. Árvores brasileiras: manual de identificação e cultivo de plantas arbóreas nativas do Brasil. Plantarum, Nova Odessa, v.1-2.

LORENZI, H. 2009. Árvores brasileiras: manual de identificação e cultivo de plantas arbóreas nativas do Brasil. Plantarum, Nova Odessa, v.3.

MARINHO-FILHO, J. \& GASTAL, M.L. 2000. Mamíferos da matas ciliares do Brasil Central. In Matas ciliares: estado atual do conhecimento (R.R. Rodrigues, org.). Fundação de Pesquisa do Estado de São Paulo, São Paulo, p.209-221.

MEIRELES, J.E. 2012. Ormosia. In Lista de Espécies da Flora do Brasil. Jardim Botânico do Rio de Janeiro, http://floradobrasil.jbrj.gov.br/2012/ FB083504 (último acesso em 20/06/2012).

MIOTTO, S.T.S., LÜDTKE, R. \& OLIVEIRA, M.L.A.A. 2008. A família Leguminosae no Parque Estadual de Itapuã, Viamão, Rio Grande do Sul, Brasil. Rev. Brasil. Bioc. 6(3):269-290.

NUNES DA CUNHA, C. 1990. Estudo florístico e fitossociológico das principais formações arbóreas do Pantanal de Poconé-MT. Dissertação de Mestrado, Universidade Estadual de Campinas, Campinas.
NUNES DA CUNHA, C. 1998. Comunidades arbustivo-arbóreas de capão e diques marginais no Pantanal de Poconé, MT: Caracterização e Análise de Gradiente. Tese de Doutorado, Universidade Federal de São Carlos, São Carlos.

NUNES DA CUNHA, C. \& JUNK, W.J. 2000. The Impact of Flooding on Distribution of Woody Plant Communities in the Pantanal of Poconé, Mato Grosso, Brazil. In Workshop on Neotropical Ecosystems - Achievements and Prospects od Cooperative Research Hamburg. German-Brazilian, p.3-8.

PENNINGTON, T.D. 1997. The genus Inga. Royal Botanic Gardens, Kew.

PEREIRA, I.M. 2006. Estudo da vegetação remanescente como subsídio à recomposição de áreas alteradas nas cabeceiras do Rio Grande, Minas Gerais - Lavras. Tese de Doutorado, Universidade Federal de Lavras, Lavras.

POLHILL, R.M., RAVEN, P.H. \& STIRTON, C.H. 1981. Evolution and systematics of the Leguminosae. In Advances in Legumes Systematics 1 (R.M. Polhill \& P.H. Raven, ed.). Royal Botanic Gardens, Kew, p.1-26.

POTT, A. \& POTT, V.J. 1994. Plantas do Pantanal. Embrapa, Brasília.

POTT, A. \& POTT, V.J. 1999. Flora do Pantanal - Listagem atual de fanerógamas. In Anais do II Simpósio sobre Recursos Naturais e Sócio-Econômicos do Pantanal, 1996. Manejo e Conservação. Embrapa Pantanal, Corumbá, p.298-325.

RODRIGUES, R. R. \& NAVE, A.G. 2004. Heterogeneidade florística das matas ciliares. In Matas ciliares: Conservação e Recuperação (R.R. Rodrigues \& Leitão Filho, H.F., eds.). São Paulo, p.148-185.

SILVA, R.R. 2010. Leguminosae do município de Poconé, Pantanal de Poconé, Mato Grosso, Brasil. Biota Neotr. 10(4):1-7.

SILVA, R.R. 2011. Leguminosae no Pantanal de Barão de Melgaço, Mato Grosso, Brasil. Biota Neotr. 11(4):353-357.

SOARES, G.F. 2009. Descrição e análise da vegetação em remanescentes de mata ciliar e áreas degradas por mineração de diamante, na Sub-bacia do Rio São Francisco, Nova Marilândia, Mato Grosso. Dissertação de Mestrado, Universidade Federal de Mato Grosso, Cuiabá.

SOUZA, V.C., BORTOLUZZI, R.L.C. 2012. Chamaecrista. In Lista de Espécies da Flora do Brasil. (Jardim Botânico do Rio de Janeiro). Jardim Botânico do Rio de Janeiro, Rio de Janeiro. http://floradobrasil.jbrj.gov. br/2012/FB027861 (último acesso em 20/06/2012).

SOUZA, V.C. \& LORENZI, H. 2008. Botânica Sistemática - guia ilustrado para identificação das famílias de fanerógamas nativas e exóticas no Brasil, baseado em APG II. Instituto Plantarum, Nova Odessa.

THIERS, B. 2012. Index Herbariorum: A global directory of public herbaria and associated staff. New York Botanical Garden's Virtual Herbarium. http://sweetgum.nybg.org/ih/ (último acesso em 20/06/2012).

VAN DER PIJL, L. 1982. Principles of dispersal in higher plants. SpringerVerlag, Berlin. http://dx.doi.org/10.1007/978-3-642-87925-8

WHITMORE, T.C. 1984. Tropical rain Forest of the far esast. Oxford Claredon Press, Oxford, England. 